medRxiv preprint doi: https://doi.org/10.1101/2021.05.11.21257037; this version posted May 11, 2021. The copyright holder for this preprint (which was not certified by peer review) is the author/funder, who has granted medRxiv a license to display the preprint in perpetuity. It is made available under a CC-BY-NC-ND 4.0 International license .

\title{
Mental health of Adolescents in the Pandemic: Long-COVID19 or Long-Pandemic Syndrome?
}

Judith Blankenburg ${ }^{1}$, MD, Magdalena K. Wekenborg ${ }^{2}$, PhD, Jörg Reichert ${ }^{1}$, PhD, Carolin Kirsten ${ }^{1}$, Elisabeth Kahre ${ }^{1}, \mathrm{MD}$, Luise Haag ${ }^{1}, \mathrm{MD}$, Leonie Schumm ${ }^{1}, \mathrm{MD}$, Paula Czyborra ${ }^{1}, \mathrm{MD}$, Reinhard Berner ${ }^{1}, \mathrm{MD}$, Jakob P. Armann ${ }^{1}$, MD

\section{Affiliations:}

${ }^{1}$ Department of Pediatrics, University Hospital and Medical Faculty Carl Gustav Carus, Technische Universität Dresden, Fetscherstrasse 74, 01307 Dresden, Germany;

${ }^{2}$ Biological Psychology, Institute of Psychology, Technische Universität Dresden, Zellescher Weg 19, 01069 Dresden, Germany

Corresponding Author: Jakob P. Armann, Department of Pediatrics, University Hospital and Medical Faculty Carl Gustav Carus, Technische Universität Dresden, Fetscherstrasse 74, 01307 Dresden, Germany; email: jakob.armann@uniklinikum-dresden.de; telephone: +49 35145818568

Clinical Trial Registration: SchoolCoviDD19: Prospektive Erfassung der SARS-CoV-2 Seropositivität bei Schulkindern nach Ende der unterrichtsfreien Zeit aufgrund der Corona-Schutz-Verordnung (COVID19), DRKS00022455, https://www.drks.de/drks web/navigate.do?navigationld=trial.HTML\&TRIAL ID=DRKS00022455 
medRxiv preprint doi: https://doi.org/10.1101/2021.05.11.21257037; this version posted May 11, 2021. The copyright holder for this preprint (which was not certified by peer review) is the author/funder, who has granted medRxiv a license to display the preprint in perpetuity.

It is made available under a CC-BY-NC-ND 4.0 International license.

\section{Abstract \\ Backround}

Post-COVID19 complications such as pediatric inflammatory multisystem syndrome (PIMS) and LongCOVID19 move increasingly into focus, potentially causing more harm in this age group than the acute infection. To better understand the symptoms of long-COVID19 in adolescents and to distinguish infection-associated symptoms from pandemic-associated symptoms, we conducted a Long-COVID19 survey, comparing responses from seropositive and seronegative adolescents. To our knowledge, data of Long-COVID19 surveys with seronegative control groups have not been published yet.

\section{Methods}

Since May 2020 students grade 8-12 in fourteen secondary schools in Eastern Saxony were enrolled in the SchoolCovid19 study. Seroprevalence was assessed via serial SARS-CoV-2 antibody testing in all participants. Furthermore, during the March/April 2021 study visit all participants were asked to complete a 12 question Long-COVID19 survey regarding the occurrence and frequency of difficulties concentrating, memory loss, listlessness, headache, abdominal pain, myalgia/ arthralgia, fatigue, insomnia and mood (sadness, anger, happiness and tenseness).

\section{Findings}

1560 students with a median age of 15 years participated in this study. $1365(88 \%)$ were seronegative, 188 (12\%) were seropositive. Each symptom was present in at least $35 \%$ of the students within the last seven days before the survey. However, there was no statistical difference comparing the reported symptoms between seropositive students and seronegative students. Whether the infection was known or unknown to the participant did not influence the prevalence of symptoms.

\section{Interpretation}

The lack of differences comparing the reported symptoms between seropositive and seronegative students suggests that Long-COVID19 might be less common than previously thought and emphasizing the impact of pandemic-associated symptoms regarding the well-being and mental health of young adolescents.

\section{Funding}

This study was supported by a grant by the Federal State of Saxony. M.K.W. was supported by the Else Kröner-Fresenius Center for Digital Health (EKFZ), TU Dresden, Germany. 
medRxiv preprint doi: https://doi.org/10.1101/2021.05.11.21257037; this version posted May 11, 2021. The copyright holder for this preprint (which was not certified by peer review) is the author/funder, who has granted medRxiv a license to display the preprint in perpetuity.

It is made available under a CC-BY-NC-ND 4.0 International license .

\section{Abbreviations:}

COVID-19 Coronavirus disease 2019

ELISA enzyme-linked immunosorbent assay

IgG Immunoglobulin G

IQR Interquartile Range

PCR Polymerase Chain Reaction

SARS-CoV-2 severe acute respiratory syndrome coronavirus type 2 
medRxiv preprint doi: https://doi.org/10.1101/2021.05.11.21257037; this version posted May 11, 2021. The copyright holder for this preprint (which was not certified by peer review) is the author/funder, who has granted medRxiv a license to display the preprint in perpetuity.

It is made available under a CC-BY-NC-ND 4.0 International license .

\section{Introduction:}

Since the identification of the severe acute respiratory syndrome coronavirus 2 (SARS-CoV-2) as the cause of COVID-19 ${ }^{1}$ in December 2019 and the beginning of the SARS-CoV-2 pandemic in Germany in March 2020 nearly 490.000 cases in children and adolescents have been reported by the RobertKoch-Institute $(\mathrm{RKI})^{2}$. In contrast to adults, children and adolescents usually have mild disease courses with a low rate of hospitalization ${ }^{3-5}$. Therefore, post-COVID19 complications such as pediatric inflammatory multisystem syndrome (PIMS) and Long-COVID19 - with persisting symptoms 4-12 weeks and more than 12 weeks after an acute SARS-CoV-2infection ${ }^{6}$ move into focus, potentially causing more harm in this age group than the acute infection.

While multiple studies and registers have provided reliable data on epidemiology, clinical presentation, disease course and treatment options on $\mathrm{PIMS}^{7-9}$ to date no comparable data exists for Long-COVID19 in children and adolescents. A cross-sectional study from Italy ${ }^{10}$ in 123 children diagnosed with a SARS-CoV-2 infection found that more than $50 \%$ of participants had at least one persisting symptom 120 days after their infection, with Insomnia, pain, fatigue, and concentration difficulties being the most commonly reported ones. An April 2021 Office for National Statistics (ONS) report from the UK ${ }^{11}$ similarly provided data that symptoms in children persisted at least 12 weeks after their SARS-CoV-2 infection.

These numbers are concerning and require attention; however, currently they merely show a temporal connection and not a causal relationship. In order to better understand the epidemiology and clinical manifestations of Long-COVID19 in children and adolescents and differentiate infectionassociated symptoms from pandemic-associated symptoms, we conducted a Long-COVID19 survey in more than 1500 students participating in the SchoolCoviDD19 study in March and April 2021.

\section{Methods:}

\section{Study Design}

Since May 2020 students grade 8-12 in fourteen secondary schools in Eastern Saxony are enrolled in the SchoolCoviDD19study. Two of these 14 schools are vocational schools. Seroprevalence is assessed via serial SARS-CoV-2 antibody assessment in all participants. During the March/April 2021 study visit all participants were asked to complete a Long-COVID19 survey. Vaccinated Students $(n=7)$ were excluded from the analysis. 
medRxiv preprint doi: https://doi.org/10.1101/2021.05.11.21257037; this version posted May 11, 2021. The copyright holder for this preprint (which was not certified by peer review) is the author/funder, who has granted medRxiv a license to display the preprint in perpetuity.

It is made available under a CC-BY-NC-ND 4.0 International license .

\section{Survey Details}

The Survey included besides sociodemographic variables (i.e., age, sex) twelve questions on the occurrence and frequency of relevant neurocognitive, pain and mood symptoms, namely difficulties concentrating, memory loss, listlessness, headache, abdominal pain, myalgia/arthralgia, fatigue, insomnia and mood (sadness, anger, happiness and tenseness) within the last seven days before the survey.

The questions were taken from the Symptom Checklist-90-R (SCL-90-R $)^{12}$, the Somatic Symptom Scale $(\mathrm{SSS}-8)^{13}$ and a questionnaire about stress and stress management in children and adolescents (SS KJ 3-8 R) ${ }^{14}$. All questionnaires are validated in adolescents.

Answers were coded on a categorical scale - "never", "once", "multiple times" for insomnia and all mood questions; "not at all", "a little bit", "quite", "severe" and "very severe" for the remaining questions.

In addition, a self-generated item was used to assess the overall level of mental distress on a scale from 0 ("not at all") to 10 ("total").

\section{Laboratory Analysis}

We assessed anti-SARS-CoV-2 IgG antibodies in all samples using a commercially available chemiluminescence immunoassay (CLIA) technology for the quantitative determination of anti-S1 and anti-S2 specific IgG antibodies to SARS-CoV-2 (Diasorin LIAISON ${ }^{\circledR}$ SARS-CoV-2 S1/S2 IgG Assay). Antibody levels $>15.0 \mathrm{AU} / \mathrm{ml}$ were considered positive and levels between 12.0 and $15.0 \mathrm{AU} / \mathrm{ml}$ were considered equivocal.

All samples with a positive or equivocal LIAISON ${ }^{\circledR}$ test result, as well as all samples from participants with a reported personal or household history of a SARS-CoV-2 infection, were re-tested with two additional serological tests. These were a chemiluminescent microparticle immunoassay (CMIA) intended for the qualitative detection of IgG antibodies to the nucleocapsid protein of SARS-CoV-2 (Abbott Diagnostics ${ }^{\circledR}$ ARCHITECT SARS-CoV-2 IgG ) (an index (S/C) of $<1.4$ was considered negative whereas one $>/=1.4$ was considered positive) and an ELISA detecting IgG against the S1 domain of the SARS-CoV-2 spike protein (Euroimmun ${ }^{\circledast}$ Anti-SARS-CoV-2 ELISA) (a ratio $<0.8$ was considered negative, $0.8-1 \cdot 1$ equivocal, $>1 \cdot 1$ positive).

Participants whose positive or equivocal LIAISON ${ }^{\circledR}$ test result could be confirmed by a positive test result in at least one additional serological test were considered seropositive. Participants with a negative LIAISON $^{\circledR}$ test result, but positive results in both additional serological tests were also considered positive. 
medRxiv preprint doi: https://doi.org/10.1101/2021.05.11.21257037; this version posted May 11, 2021. The copyright holder for this preprint (which was not certified by peer review) is the author/funder, who has granted medRxiv a license to display the preprint in perpetuity.

It is made available under a CC-BY-NC-ND 4.0 International license .

\section{Statistical Analysis}

Results for continuous variables are presented as medians with interquartile ranges (IQR) and categorical variables as numbers with percentages, unless stated otherwise.

Fisher's exact test was used to determine categorical variables for the statistical analysis. Thereby, the answers to the items assessing neurocognitive, pain and mood symptoms, were dummy-coded, enabling a comparison of the answer category "none" (coded 0 ) against the answer categories "a little bit"/ "quite"/ "severe"/ "very severe" and "once"/ "multiple times" (coded 1), respectively. Furthermore, data distributions of the neurocognitive, pain and mood symptoms were tested for normality using the Kolmogorov-Smirnov (K-S) test. Data with distributions significantly different $(p<$ 0.05 ) from normal were either transformed to ranks to allow parametric statistics or analyzed using non-parametric statistics.

In order to examine associations between sociodemographic variables (i.e., age, sex) and the neurocognitive and pain symptoms, bivariate correlation analyses were conducted.

In a second step, partial correlation analyses were conducted between serostatus and the neurocognitive and pain symptoms, adjusting for age and sex.

Analyses were performed using IBM SPSS 27.0 or Microsoft Excel 2010. All statistical tests were conducted with $\alpha<0.05$.

\section{Approval}

The SchoolCoviDD19 study was approved by the Ethics Committee of the Technische Universität (TU) Dresden (BO-EK-156042020) and has been assigned clinical trial number DRKS00022455.

\section{Role of the funding source}

The funder of the study had no role in the study design, data collection, data analysis, data interpretation, or writing of the report and in the decision to submit the paper for publication.

\section{Results:}

1560 students with a median age of 15 years participated at the study visit in March/April 2021 and had their serostatus analyzed. Seven already vaccinated students were excluded from the analysis, 
medRxiv preprint doi: https://doi.org/10.1101/2021.05.11.21257037; this version posted May 11, 2021. The copyright holder for this preprint (which was not certified by peer review) is the author/funder, who has granted medRxiv a license to display the preprint in perpetuity.

It is made available under a CC-BY-NC-ND 4.0 International license .

$1365(88 \%)$ were seronegative and 188 (12\%) were seropositive. Median age, sex and household size did not differ significantly between seropositive and seronegative participants (table 1).

Long-COVID19 survey was answered by at least 1504 (96.8\%) of the participants. Each symptom, regardless of the expression, was present in at least $35 \%$ of the students within the last seven days before the survey, most commonly happiness (98.7\%) followed by tenseness ( $86.4 \%)$, listlessness $(80 \cdot 7 \%)$ and difficulties concentrating (79.3\%). Myalgia/arthralgia (35.6\%) and fatigue $(37 \cdot 8 \%)$ were reported least commonly. (see table 2 for full results).

Fisher's exact test did not reveal any significant differences between seropositive and seronegative students regarding the prevalence of any of the neurocognitive and pain symptoms reported (figure 1).

To avoid underestimation of seropositive individuals due to our relatively strict definitions of seropositivity, we also analyzed the data if only the LIAISON ${ }^{\circledR}$ test result was taken into consideration for the decision on seropositivity. This resulted in 204 (13\%) LIAISON ${ }^{\circledR}$-seropositive and 1342 (86\%) seronegative students. There was no statistical difference (Fisher's exact test) in the occurrence of any neurocognitive, pain or mood symptoms between these LIAISON ${ }^{\circledR}$-seropositive and seronegative students either (see Supplementals - figure 1).

Spearman correlation analyses revealed that age was positive correlate with nearly all neurocognitive and pain symptoms, except for insomnia, sad mood and angry mood (table 3 ). In addition, females reported a consistently higher prevalence of neurocognitive and pain symptoms compared to men, except for Myalgia Arthralgia where there was no significant association with sex.

Partial correlation analyses, which were performed to test for age and sex independent effects of the analysed serostatus on rank-transformed neurocognitive and pain symptoms revealed differences only with respect to sadness; with being seronegative was associated with an increased prevalence of sadness (table 4).

104 out 188 seropositive students (55\%) had previously been tested positive for SARS-CoV-2 and/ or reported a confirmed SARS-CoV-2 positive household member and were therefore considered as known SARS-CoV2 infections. Compared to those with an unknown infection (84/188 (45\%)) Fisher's exact test did not reveal any significant differences regarding the prevalence of any of the neurocognitive and pain symptoms reported either (table 5).

The median score of self-reported mental distress was 4 and did not differ between seropositive and seronegative participants. 
medRxiv preprint doi: https://doi.org/10.1101/2021.05.11.21257037; this version posted May 11, 2021. The copyright holder for this preprint (which was not certified by peer review) is the author/funder, who has granted medRxiv a license to display the preprint in perpetuity.

It is made available under a CC-BY-NC-ND 4.0 International license .

\section{Discussion:}

The data presented in our study clearly shows a high rate of neurocognitive, pain and mood symptoms in the surveyed group of adolescents, with every item being present in at least one third of the students within the last seven days before responding to the survey. This is consistent with previous studies and surveys on the prevalence of Long-COVID19 symptoms ${ }^{10}$ or psychosomatic symptoms during the SARS-CoV-2 pandemic ${ }^{15}$ in this age group. Furthermore the prevalence is considerably higher compared to pre-pandemic data. ${ }^{15}$

Our study can know provide a control group to SARS-CoV-2 infected adolescents by comparing the responses of seropositive individuals to those of their seronegative peers which has not been published so far.

The differentiation between infection-associated and pandemic-associated symptoms is important because the approach to mediate these symptoms will be different. While strict lock-down measures including school closures will prevent SARS-CoV-2 transmissions in this age group and thereby prevent long-term infection related illnesses, these measures will also further restrict social contact, self-determination, education and development of the affected children and adolescents and thereby amplify pandemic- or lockdown-associated symptoms.

The equal prevalence of neurocognitive, pain and mood symptoms in seronegative and seropositive adolescents in our study does not negate the existence of Long-COVID19 symptoms in general or in the pediatric population. However, it does suggest that they occur less frequently than previously assumed - at least in children and adolescents with only mild to asymptomatic courses of disease as were investigated by this study.

Furthermore, it confirms the negative effects of lockdown measures on mental health and well-being of children and adolescents ${ }^{16}$. These effects - affecting this whole age group - need to be balanced with the risk of Long-COVID19 in infected individuals. This balancing act will be a difficult task for public health officials and political officials. Nevertheless, it will be a necessary one when aiming to improve mental health in adolescents.

While self-reported symptoms cannot be equated with the diagnosis of an illness, a prevalence of at least $35 \%$ for each symptom is a concerning screening result that requires further investigation. In addition, validated, reliable tests are needed to evaluate symptom severity in affected individuals. The fact that self-reported overall mental distress did not differ significantly between seropositive 
medRxiv preprint doi: https://doi.org/10.1101/2021.05.11.21257037; this version posted May 11, 2021. The copyright holder for this preprint (which was not certified by peer review) is the author/funder, who has granted medRxiv a license to display the preprint in perpetuity.

It is made available under a CC-BY-NC-ND 4.0 International license .

and seronegative individuals does not suggest though that infection-associated symptoms are necessarily more severe than pandemic associated symptoms. The interpretation of the negative correlation of sadness and positive serostatus in the partial correlation analyses is difficult and should be but not the overstated given the fact that the group (none vs. any) comparison did not yield significant results and the fact, that this was an exploratory study design. Nevertheless, this finding warrants further investigation.

As a positive takeaway the fact that happiness is by far the most common response in our survey is reassuring und clearly points to the resilience of this age group.

There are several limitations to our study. The sample size of around 180 infected individuals is not large enough to detect rare symptoms and a screening questionnaire cannot reliably compare the severity of symptoms in affected individuals. Furthermore, our questionnaire concentrated on neurocognitive, general pain and mood symptoms. Symptoms like a persistent sore throat, persistent cough or chest tightness and an altered sense of smell/ taste were not included.

However, our survey covers a variety of symptoms reported in the context of Long-COVID19 and having a control group of age-matched peers who never had a SARS-CoV-2 infection adds valuable information to the Long-COVID19 discussion that is urgently needed.

\section{Conclusion:}

In our cohort of adolescents more than one third reported the presence of at least one neurocognitive, pain or mood symptom with tenseness, listlessness and difficulties concentrating being reported most commonly. However, there was no statistical difference comparing the reported symptoms between seropositive students - with mild to asymptomatic courses of SARS-CoV-2 infections - and seronegative students. Leading to the conclusion that symptoms of Long-COVID19 might be less common than previously assumed and emphasizing on the impact of pandemicassociated symptoms regarding the well-being and mental health of young adolescents.

\section{Research in context}

\section{Evidence before this study}

We searched PubMed for articles published between January 1, 2020, and May 1, 2021, using the search terms ("Long-Covid19") AND ("adolescent") AND ("children"). We identified 1 relevant cross 
medRxiv preprint doi: https://doi.org/10.1101/2021.05.11.21257037; this version posted May 11, 2021. The copyright holder for this preprint (which was not certified by peer review) is the author/funder, who has granted medRxiv a license to display the preprint in perpetuity.

It is made available under a CC-BY-NC-ND 4.0 International license .

sectional study and 1 case series. Persisting symptoms up to 120 days after the SARS-CoV-2 infection were reported in at least $50 \%$ of children and adolescents.

Added value of this study

By adding a control group this study documents that there is no significant difference in the prevalence of neurocognitive, pain and mood symptoms in seropositive compared to seronegative adolescents. This suggests that pandemic- and lockdown-associated factors affect the mental health of adolescents more than infection-associated factors.

Implications of all the available evidence

These findings add relevant new data that will help to inform scientists, public health authorities and policy makers in regard to future policy measures in an ongoing pandemic.

\section{Acknowledgements:}

We thank the Federal State of Saxony for supporting this study by a financial grant.

We thank J. Schneider for her support and excellent organization of the study visit March/ April 2021.

We thank J. Herrmann and K. Jackisch for their great support in collecting all samples.

Declaration of interests: Reinhard Berner and Jakob P. Armann report grants from the Federal State of Saxony during the conduct of the study. The other authors have no conflicts of interest to disclose.

\section{Contributors:}

J.A and R.B. designed the study and wrote the protocol. J.A., J.B., M.W., J.R. and R.B. designed the Long-COVID19 Survey. J.A., J.B., C.K., L.H., E.K., L.S., P.C. collected samples. J.A., J.B. and M.W. analyzed and verified the data. J.A. , J.B. and M.W. wrote the manuscript. M.W., R.B., C.K., L.H., E.K., L.S., P.C. reviewed the manuscript.

All corresponding authors had full access to all the data in the study and had final responsibility for the decision to submit for publication.

\section{Data Sharing:}


medRxiv preprint doi: https://doi.org/10.1101/2021.05.11.21257037; this version posted May 11, 2021. The copyright holder for this preprint (which was not certified by peer review) is the author/funder, who has granted medRxiv a license to display the preprint in perpetuity.

It is made available under a CC-BY-NC-ND 4.0 International license .

Deidentified individual participant data will be made available, in addition to study protocols, the statistical analysis plan, and the informed consent form. The data will be made available upon publication to researchers who provide a methodologically sound proposal for use in achieving the goals of the approved proposal. Proposals should be submitted to corresponding author (jakob.armann@uniklinikum-dresden.de).

\section{References}

1 Zhu N, Zhang D, Wang W, et al. A Novel Coronavirus from Patients with Pneumonia in China, 2019. N Eng/ J Med 2020; 382: 727-33. https://doi.org/10.1056/NEJMoa2001017.

2 RKI - Coronavirus SARS-CoV-2 - COVID-19-Fälle nach Altersgruppe und Meldewoche (Tabelle wird jeden Dienstag aktualisiert).

https://www.rki.de/DE/Content/InfAZ/N/Neuartiges_Coronavirus/Daten/Altersverteilung.html (accessed May 03, 2021).

3 Mehta NS, Mytton OT, Mullins EWS, et al. SARS-CoV-2 (COVID-19): What Do We Know About Children? A Systematic Review. Clin Infect Dis 2020; 71: 2469-79. https://doi.org/10.1093/cid/ciaa556.

4 Armann JP, Diffloth N, Simon A, et al. Hospital Admission in Children and Adolescents With COVID-19. Dtsch Arztebl Int 2020; 117: 373-74. https://doi.org/10.3238/arztebl.2020.0373.

5 DGPI: Deutsche Gesellschaft für Pädiatrische Infektiologie. COVID-19 Survey-Update: 2021, Kalenderwoche 17. https://dgpi.de/covid-19-survey-update/ (accessed May 03, 2021).

6 Overview | COVID-19 rapid guideline: managing the long-term effects of COVID-19 | Guidance | NICE. https://www.nice.org.uk/guidance/ng188 (accessed May 06, 2021).

7 DGPI: Deutsche Gesellschaft für Pädiatrische Infektiologie. PIMS Survey Update: 2021, Kalenderwoche 17. https://dgpi.de/pims-survey-update/ (accessed May 03, 2021).

8 Harwood R, Allin B, Jones CE, et al. A national consensus management pathway for paediatric inflammatory multisystem syndrome temporally associated with COVID-19 (PIMS-TS): results of a national Delphi process. The Lancet Child \& Adolescent Health 2021; 5: 133-41. https://doi.org/10.1016/S2352-4642(20)30304-7.

9 Feldstein LR, Tenforde MW, Friedman KG, et al. Characteristics and Outcomes of US Children and Adolescents With Multisystem Inflammatory Syndrome in Children (MIS-C) Compared With Severe Acute COVID-19. JAMA 2021; 325: 1074-87. https://doi.org/10.1001/jama.2021.2091.

10 Buonsenso $\mathrm{D}$, Munblit $\mathrm{D}$, Rose $\mathrm{C}$ de, et al. Preliminary evidence on long COVID in children. Acta Paediatr 2021. https://doi.org/10.1111/apa.15870.

11 Ayoubkhani D. Office for National Statistics 01.04.2021.

12 Franke G. Die Symptom-Checkliste von Derogatis (SCL-90-R) - Deutsche Version - Manual, 2002.

13 Gierk B, Kohlmann S, Kroenke K, et al. The somatic symptom scale-8 (SSS-8): a brief measure of somatic symptom burden. JAMA Intern Med 2014; 174: 399-407. https://doi.org/10.1001/jamainternmed.2013.12179.

14 Lohaus A, Eschenbeck H, Kohlmann C-W, Klein-Heßling J. Fragebogen zur Erhebung von Stress und Stressbewältigung im Kindes- und Jugendalter (SSKJ 3-8). Göttingen: Hogrefe; 2006., 2006.

15 Ravens-Sieberer U, Kaman A, Otto C, et al. Mental Health and Quality of Life in Children and Adolescents During the COVID-19 Pandemic-Results of the Copsy Study. Dtsch Arztebl Int 2020; 117: 828-29. https://doi.org/10.3238/arztebl.2020.0828. 
medRxiv preprint doi: https://doi.org/10.1101/2021.05.11.21257037; this version posted May 11, 2021. The copyright holder for this preprint (which was not certified by peer review) is the author/funder, who has granted medRxiv a license to display the preprint in perpetuity.

It is made available under a CC-BY-NC-ND 4.0 International license .

16 Figueiredo CS de, Sandre PC, Portugal LCL, et al. COVID-19 pandemic impact on children and adolescents' mental health: Biological, environmental, and social factors. Prog

Neuropsychopharmacol Biol Psychiatry 2021; 106: 110171.

https://doi.org/10.1016/j.pnpbp.2020.110171. 
medRxiv preprint doi: https://doi.org/10.1101/2021.05.11.21257037; this version posted May 11, 2021. The copyright holder for this preprint (which was not certified by peer review) is the author/funder, who has granted medRxiv a license to display the preprint in perpetuity.

It is made available under a CC-BY-NC-ND 4.0 International license .

Table 1) Demographic data and serostatus of the participating students at study visit in March/ April 2021; IQR - Interquartile range

\begin{tabular}{|l|l|l|}
\hline & Seronegative Students & Seropositive Students \\
\hline Age (median/IQR), (range) & $15(14-16),(10-38)$ & $15(14-17),(10-35)$ \\
\hline Female (n/\%) & $762(56)$ & $104(55)$ \\
\hline Houshold size (median/IQR) & $4(3-5)$ & $4(4-5)$ \\
\hline
\end{tabular}

Table 2) All answers of seronegative (-) and seropositive (+) participants to the Long-COVID19-survey

\begin{tabular}{|c|c|c|c|c|c|c|c|c|c|c|}
\hline & \multicolumn{2}{|c|}{ Not at all } & \multicolumn{2}{|c|}{ A little bit } & \multicolumn{2}{|c|}{ Quite } & \multicolumn{2}{|c|}{ Severe } & \multicolumn{2}{|c|}{ Very severe } \\
\hline Item Serostatus & - & + & - & + & - & + & - & + & - & + \\
\hline $\begin{array}{l}\text { Difficulty } \\
\text { concentrating }\end{array}$ & $\begin{array}{l}278 \\
(20 \cdot 9)\end{array}$ & $\begin{array}{l}34 \\
(19 \cdot 1)\end{array}$ & $\begin{array}{l}710 \\
(53 \cdot 5)\end{array}$ & $\begin{array}{l}98 \\
(55 \cdot 1)\end{array}$ & $\begin{array}{l}230 \\
(17 \cdot 3)\end{array}$ & $\begin{array}{l}23 \\
(12 \cdot 9)\end{array}$ & $\begin{array}{l}88 \\
(6 \cdot 6)\end{array}$ & $\begin{array}{l}19 \\
(10 \cdot 7)\end{array}$ & $\begin{array}{l}21 \\
(1 \cdot 6)\end{array}$ & $\begin{array}{l}4 \\
(2 \cdot 2)\end{array}$ \\
\hline Memory loss & $\begin{array}{l}709 \\
(53 \cdot 4)\end{array}$ & $\begin{array}{l}87 \\
(48.9)\end{array}$ & $\begin{array}{l}478 \\
(36 \cdot 0)\end{array}$ & $\begin{array}{l}60 \\
(33 \cdot 7)\end{array}$ & $\begin{array}{l}104 \\
(7 \cdot 8)\end{array}$ & $\begin{array}{l}18 \\
(10 \cdot 1)\end{array}$ & $\begin{array}{l}28 \\
(2 \cdot 1) \\
\end{array}$ & $\begin{array}{l}12 \\
(6 \cdot 7)\end{array}$ & $\begin{array}{l}9 \\
(0 \cdot 7)\end{array}$ & $\begin{array}{l}1 \\
(0 \cdot 6)\end{array}$ \\
\hline Listlessness & $\begin{array}{l}251 \\
(18.9)\end{array}$ & $\begin{array}{l}39 \\
(21 \cdot 9)\end{array}$ & $\begin{array}{l}500 \\
(37 \cdot 7)\end{array}$ & $\begin{array}{l}64 \\
(36 \cdot 0)\end{array}$ & $\begin{array}{l}329 \\
(24 \cdot 8)\end{array}$ & $\begin{array}{l}36 \\
(20 \cdot 2)\end{array}$ & $\begin{array}{l}178 \\
(13 \cdot 4)\end{array}$ & $\begin{array}{l}30 \\
(16 \cdot 9)\end{array}$ & $\begin{array}{l}68 \\
(5 \cdot 1)\end{array}$ & $\begin{array}{l}9 \\
(5 \cdot 1)\end{array}$ \\
\hline Headache & $\begin{array}{l}598 \\
(45 \cdot 1) \\
\end{array}$ & $\begin{array}{l}69 \\
(38 \cdot 8) \\
\end{array}$ & $\begin{array}{l}387 \\
(29 \cdot 2) \\
\end{array}$ & $\begin{array}{l}51 \\
(28 \cdot 7) \\
\end{array}$ & $\begin{array}{l}233 \\
(17 \cdot 6) \\
\end{array}$ & $\begin{array}{l}38 \\
(21 \cdot 3) \\
\end{array}$ & $\begin{array}{l}83 \\
(6 \cdot 3) \\
\end{array}$ & $\begin{array}{l}19 \\
(10 \cdot 7) \\
\end{array}$ & $\begin{array}{l}25 \\
(1.9) \\
\end{array}$ & $\begin{array}{l}1 \\
(0 \cdot 6) \\
\end{array}$ \\
\hline $\begin{array}{l}\text { Abdominal } \\
\text { pain }\end{array}$ & $\begin{array}{l}794 \\
(59 \cdot 8)\end{array}$ & $\begin{array}{l}96 \\
(53.9)\end{array}$ & $\begin{array}{l}317 \\
(23,9)\end{array}$ & $\begin{array}{l}43 \\
(24 \cdot 2)\end{array}$ & $\begin{array}{l}152 \\
(11 \cdot 5)\end{array}$ & $\begin{array}{l}26 \\
(14 \cdot 6)\end{array}$ & $\begin{array}{l}52 \\
(3 \cdot 9)\end{array}$ & $\begin{array}{l}7 \\
(3 \cdot 9)\end{array}$ & $\begin{array}{l}12 \\
(0 \cdot 9)\end{array}$ & $\begin{array}{l}6 \\
(3 \cdot 4)\end{array}$ \\
\hline $\begin{array}{l}\text { Myalgia/ } \\
\text { Arthralgia }\end{array}$ & $\begin{array}{l}851 \\
(64 \cdot 1)\end{array}$ & $\begin{array}{l}116 \\
(65 \cdot 2)\end{array}$ & $\begin{array}{l}312 \\
(23,5)\end{array}$ & $\begin{array}{l}37 \\
(20 \cdot 8)\end{array}$ & $\begin{array}{l}124 \\
(9 \cdot 3)\end{array}$ & $\begin{array}{l}18 \\
(10 \cdot 1)\end{array}$ & $\begin{array}{l}34 \\
(2 \cdot 6)\end{array}$ & $\begin{array}{l}6 \\
(3 \cdot 4)\end{array}$ & $\begin{array}{l}7 \\
(0 \cdot 5)\end{array}$ & $\begin{array}{l}1 \\
(0 \cdot 6)\end{array}$ \\
\hline \multirow[t]{2}{*}{ Fatigue } & $\begin{array}{l}831 \\
(62 \cdot 6) \\
\end{array}$ & $\begin{array}{l}107 \\
(60 \cdot 1) \\
\end{array}$ & $\begin{array}{l}334 \\
(25,2) \\
\end{array}$ & $\begin{array}{l}44 \\
(24 \cdot 7) \\
\end{array}$ & $\begin{array}{l}121 \\
(9 \cdot 1) \\
\end{array}$ & $\begin{array}{l}19 \\
(10 \cdot 7) \\
\end{array}$ & $\begin{array}{l}32 \\
(2 \cdot 4) \\
\end{array}$ & $\begin{array}{l}8 \\
(4 \cdot 5) \\
\end{array}$ & $\begin{array}{l}9 \\
(0.7) \\
\end{array}$ & $\begin{array}{l}0 \\
(0)\end{array}$ \\
\hline & \multicolumn{2}{|c|}{ Never } & \multicolumn{2}{|c|}{ Once } & \multicolumn{2}{|c|}{$\begin{array}{c}\text { Multiple } \\
\text { times }\end{array}$} & & & & \\
\hline Item Serostatus & - & + & - & + & - & + & & & & \\
\hline Insomnia & $\begin{array}{l}450 \\
(34 \cdot 0) \\
\end{array}$ & $\begin{array}{l}66 \\
(37 \cdot 1) \\
\end{array}$ & $\begin{array}{l}418 \\
(31,6) \\
\end{array}$ & $\begin{array}{l}53 \\
(29 \cdot 8) \\
\end{array}$ & $\begin{array}{l}456 \\
(34 \cdot 4) \\
\end{array}$ & $\begin{array}{l}59 \\
(33 \cdot 1)\end{array}$ & & & & \\
\hline Mood - Sad & $\begin{array}{l}447 \\
(33.7) \\
\end{array}$ & $\begin{array}{l}75 \\
(42 \cdot 1) \\
\end{array}$ & $\begin{array}{l}428 \\
(32,2) \\
\end{array}$ & $\begin{array}{l}1 \\
(28 \cdot 7) \\
\end{array}$ & $\begin{array}{l}453 \\
(34 \cdot 1) \\
\end{array}$ & $\begin{array}{l}52 \\
(29 \cdot 2) \\
\end{array}$ & & & & \\
\hline Mood - Angry & $\begin{array}{l}422 \\
(31 \cdot 8)\end{array}$ & $\begin{array}{l}59 \\
(33 \cdot 1)\end{array}$ & $\begin{array}{l}506 \\
(38,1)\end{array}$ & $\begin{array}{l}73 \\
(41 \cdot 0) \\
\end{array}$ & $\begin{array}{l}399 \\
(30 \cdot 1) \\
\end{array}$ & $\begin{array}{l}46 \\
(25 \cdot 8) \\
\end{array}$ & & & & \\
\hline Mood - Happy & $\begin{array}{l}15 \\
(1 \cdot 1)\end{array}$ & $\begin{array}{l}4 \\
(2 \cdot 2) \\
\end{array}$ & $\begin{array}{l}88 \\
(6,6) \\
\end{array}$ & $\begin{array}{l}8 \\
(4 \cdot 5) \\
\end{array}$ & $\begin{array}{l}1225 \\
(92 \cdot 2)\end{array}$ & $\begin{array}{l}166 \\
(93.3)\end{array}$ & & & & \\
\hline Mood - tense & $\begin{array}{l}181 \\
(13 \cdot 6)\end{array}$ & $\begin{array}{l}23 \\
(12 \cdot 9)\end{array}$ & $\begin{array}{l}498 \\
(37,5)\end{array}$ & $\begin{array}{l}72 \\
(40 \cdot 4)\end{array}$ & $\begin{array}{l}648 \\
(48 \cdot 8)\end{array}$ & $\begin{array}{l}83 \\
(46 \cdot 6)\end{array}$ & & & & \\
\hline
\end{tabular}


Table 3) Spearman-Rho bivariate correlations between age, sex, and the reported neurocognitive, pain and mood symptoms $(\mathrm{n}=1553, *$ significant at level $0 \cdot 05$,

** significant at level 0.01 (one-tailed test))

\begin{tabular}{|c|c|c|c|c|c|c|c|c|c|c|c|c|c|c|}
\hline Variable & (1) & $(2)$ & (3) & (4) & (5) & (6) & (7) & (8) & (9) & (10) & $(11)$ & $(12)$ & (13) & (14) \\
\hline \multicolumn{15}{|l|}{ (1) Age } \\
\hline (2) sex & -.05 & & & & & & & & & & & & & \\
\hline (3) Distress & $\cdot 23 * *$ & $\cdot 25 * *$ & & & & & & & & & & & & \\
\hline (4) Concentration & $.08 * *$ & $\cdot 14^{* *}$ & $\cdot 35^{* *}$ & & & & & & & & & & & \\
\hline (5) Memory & $\cdot 10^{* *}$ & $.07 * *$ & $\cdot 24 * *$ & $\cdot 47^{* *}$ & & & & & & & & & & \\
\hline (6) Listlessness & $\cdot 17^{* *}$ & $.08 * *$ & $\cdot 36 * *$ & $.52 * *$ & $\cdot 32 * *$ & & & & & & & & & \\
\hline (7) Headache & $\cdot 10 * *$ & $\cdot 27 * *$ & $\cdot 30 * *$ & $\cdot 30 * *$ & $\cdot 23^{* *}$ & $\cdot 27^{* *}$ & & & & & & & & \\
\hline (8) Abdominal Pain & $.05 *$ & $\cdot 21 * *$ & $\cdot 26 * *$ & $\cdot 21 * *$ & $\cdot 20 * *$ & $\cdot 23^{* *}$ & $\cdot 28 * *$ & & & & & & & \\
\hline (9) Myalgia Arthralgia & $-.07 *$ & .05 & $\cdot 15^{* *}$ & $\cdot 24 * *$ & $\cdot 21 * *$ & $\cdot 20 * *$ & $\cdot 21 * *$ & $\cdot 26 * *$ & & & & & & \\
\hline (10) Fatigue & $\cdot 11^{* *}$ & $\cdot 10 * *$ & $\cdot 26 * *$ & $\cdot 32 * *$ & $\cdot 25 * *$ & $\cdot 29 * *$ & $\cdot 28 * *$ & $\cdot 27^{* *}$ & $\cdot 35^{* *}$ & & & & & \\
\hline (11) Insomina & .04 & $\cdot 20 * *$ & $\cdot 30 * *$ & $\cdot 28 * *$ & $\cdot 23^{* *}$ & $\cdot 22 * *$ & $\cdot 29 * *$ & $\cdot 18^{* *}$ & $\cdot 18 * *$ & $\cdot 24 * *$ & & & & \\
\hline (12) Sad & .04 & $\cdot 38 * *$ & $.48 * *$ & $\cdot 35^{* *}$ & $\cdot 27^{* *}$ & $\cdot 33^{* *}$ & $\cdot 30 * *$ & $\cdot 28 * *$ & $\cdot 18^{* *}$ & $\cdot 27^{* *}$ & $\cdot 37 * *$ & & & \\
\hline (13) Angry & -.04 & $\cdot 12 * *$ & $\cdot 24 * *$ & $\cdot 23^{* *}$ & $\cdot 20 * *$ & $\cdot 22 * *$ & $\cdot 17^{* *}$ & $\cdot 18^{* *}$ & $\cdot 14^{* *}$ & $\cdot 16^{* *}$ & $\cdot 23 * *$ & $.33 * *$ & & \\
\hline (14) Нарру & $-.05 *$ & $.06 *$ & $-\cdot 11^{*}$ & $-\cdot 17^{* *}$ & $-\cdot 12 * *$ & $-\cdot 17^{* *}$ & $-.06 *$ & $-.05^{*}$ & $-.07 * *$ & $-\cdot 11^{* *}$ & $-\cdot 12 * *$ & $-\cdot 11^{* *}$ & $-.06 *$ & \\
\hline (15) Tense & $\cdot 14^{* *}$ & $\cdot 16 * *$ & $\cdot 33 * *$ & $\cdot 29 * *$ & $\cdot 23^{* *}$ & $\cdot 30 * *$ & $\cdot 20 * *$ & $\cdot 20 * *$ & $\cdot 14^{* *}$ & $\cdot 23^{* *}$ & $\cdot 25^{* *}$ & $\cdot 36^{* *}$ & $\cdot 28 * *$ & $-.07 * *$ \\
\hline
\end{tabular}


Table 4) Partial correlations between serostatus and neurocognitive, pain and mood symptoms (rank-transformed), controlling for age and sex ( $\mathrm{n}=1553, *$ significant at level $0.05,{ }^{* *}$ significant at level 0.01 (one-tailed test))

\begin{tabular}{|c|c|c|c|c|c|c|c|c|c|c|c|c|c|}
\hline Variable & (1) & (2) & (3) & (4) & (5) & (6) & (7) & (8) & (9) & (10) & (11) & $(12)$ & (13) \\
\hline (1) Serostatus & & & & & & & & & & & & & \\
\hline (2) Mental Distress & -.01 & & & & & & & & & & & & \\
\hline (3) Concentration & .02 & $\cdot 33^{* *}$ & & & & & & & & & & & \\
\hline (4) Memory & .05 & $\cdot 22^{* *}$ & $.47^{* *}$ & & & & & & & & & & \\
\hline (5) Listlessness & -.01 & $\cdot 34 * *$ & $.51 * *$ & $\cdot 31 * *$ & & & & & & & & & \\
\hline (6) Headache & .05 & $\cdot 24^{* *}$ & $\cdot 27^{* *}$ & $\cdot 21 * *$ & $\cdot 24^{* *}$ & & & & & & & & \\
\hline (7) Abdominal Pain & .05 & $\cdot 22^{* *}$ & $\cdot 18^{* *}$ & $\cdot 18^{* *}$ & $\cdot 22^{* *}$ & $\cdot 23^{* *}$ & & & & & & & \\
\hline (8) Myalgia Arthralgia & $<-.01$ & $\cdot 16^{* *}$ & $\cdot 23 * *$ & $\cdot 21 * *$ & $\cdot 20 * *$ & $\cdot 20 * *$ & $\cdot 26 * *$ & & & & & & \\
\hline (9) Fatigue & .02 & $\cdot 23 * *$ & $\cdot 31 * *$ & $\cdot 24^{* *}$ & $\cdot 27^{* *}$ & $\cdot 25^{* *}$ & $\cdot 25^{* *}$ & $\cdot 35^{* *}$ & & & & & \\
\hline (10) Insomina & -.02 & $\cdot 26 * *$ & $\cdot 26 * *$ & $\cdot 22 * *$ & $\cdot 20 * *$ & $\cdot 25^{* *}$ & $\cdot 14^{* *}$ & $\cdot 18^{* *}$ & $\cdot 23 * *$ & & & & \\
\hline (11) Sad & $-.06 *$ & $.44^{* *}$ & $\cdot 32 * *$ & $\cdot 25^{* *}$ & $.32 * *$ & $\cdot 22^{* *}$ & $\cdot 22 * *$ & $\cdot 17^{* *}$ & $\cdot 25^{* *}$ & $.32 * *$ & & & \\
\hline (12) Angry & -.02 & $\cdot 22 * *$ & $\cdot 22 * *$ & $\cdot 20 * *$ & $\cdot 21^{* *}$ & $\cdot 15^{* *}$ & $\cdot 18^{* *}$ & $\cdot 13^{* *}$ & $\cdot 15^{* *}$ & $\cdot 22 * *$ & $\cdot 31 * *$ & & \\
\hline (13) Happy & .01 & $-\cdot 12 * *$ & $-\cdot 17^{* *}$ & $-\cdot 12 * *$ & $-\cdot 17^{* *}$ & $-.07 * *$ & $-.07 *$ & $-.08 * *$ & $-\cdot 11^{* *}$ & $-\cdot 13 * *$ & $-\cdot 14 * *$ & $-.07 *$ & \\
\hline (14) Tense & -.02 & $\cdot 28 * *$ & $\cdot 27^{* *}$ & $\cdot 22 * *$ & $\cdot 28^{* *}$ & $\cdot 16^{* *}$ & $\cdot 17^{* *}$ & $\cdot 15^{* *}$ & $\cdot 21^{* *}$ & $\cdot 22^{* *}$ & $\cdot 31^{* *}$ & $\cdot 27^{* *}$ & $-.07 * *$ \\
\hline
\end{tabular}


medRxiv preprint doi: https://doi.org/10.1101/2021.05.11.21257037; this version posted May 11, 2021. The copyright holder for this preprint (which was not certified by peer review) is the author/funder, who has granted medRxiv a license to display the preprint in perpetuity.

It is made available under a CC-BY-NC-ND 4.0 International license .

Table 5) Answers of seropositive participants to the Long-COVID19-survey - known vs. previously unknown infection (Fisher's exact test: $\mathrm{n}=1553, *$ significant at level 0.05 )

\begin{tabular}{|c|c|c|c|c|c|}
\hline & \multicolumn{2}{|l|}{ None } & \multicolumn{2}{|l|}{ Any } & \multirow[t]{2}{*}{$\mathbf{p}$} \\
\hline & $\begin{array}{l}\text { known } \\
\text { infection }\end{array}$ & $\begin{array}{l}\text { unknown } \\
\text { infection }\end{array}$ & $\begin{array}{l}\text { known } \\
\text { infection }\end{array}$ & $\begin{array}{l}\text { unknown } \\
\text { infection }\end{array}$ & \\
\hline $\begin{array}{l}\text { Difficulty } \\
\text { concentrating }\end{array}$ & $22(22 \cdot 5)$ & $12(15 \cdot 0)$ & $76(77 \cdot 6)$ & $68(85 \cdot 0)$ & NS \\
\hline Memory loss & $47(48 \cdot 0)$ & $40(50 \cdot 0)$ & $51(52 \cdot 0)$ & $40(50 \cdot 0)$ & NS \\
\hline Listlessness & $21(21 \cdot 4)$ & $18(22 \cdot 5)$ & $77(78 \cdot 6)$ & $62(77 \cdot 5)$ & NS \\
\hline Headache & $40(40 \cdot 8)$ & $29(36 \cdot 3)$ & $58(59 \cdot 2)$ & $51(63 \cdot 8)$ & NS \\
\hline Abdominal pain & $55(56 \cdot 1)$ & $41(51 \cdot 2)$ & $43(43 \cdot 9)$ & $39(48 \cdot 8)$ & NS \\
\hline Myalgia/Arthralgia & $64(65 \cdot 3)$ & $52(65 \cdot 0)$ & $34(34 \cdot 7)$ & $28(35 \cdot 0)$ & NS \\
\hline \multirow[t]{3}{*}{ Fatigue } & $61(62 \cdot 2)$ & $46(57 \cdot 5)$ & $37(37 \cdot 8)$ & $34(42 \cdot 5)$ & NS \\
\hline & \multicolumn{2}{|l|}{ Never } & \multicolumn{2}{|c|}{ At least once } & $\mathbf{p}$ \\
\hline & $\begin{array}{l}\text { known } \\
\text { infection }\end{array}$ & $\begin{array}{l}\text { unknown } \\
\text { infection }\end{array}$ & $\begin{array}{l}\text { known } \\
\text { infection }\end{array}$ & $\begin{array}{l}\text { unknown } \\
\text { infection }\end{array}$ & \\
\hline Insomnia & $35(35 \cdot 7)$ & $31(38 \cdot 8)$ & $63(64 \cdot 3)$ & $49(61 \cdot 3 \%)$ & NS \\
\hline Mood - Sad & $41(41 \cdot 8)$ & $34(42 \cdot 5)$ & $57(58 \cdot 2)$ & $46(57 \cdot 58)$ & NS \\
\hline Mood - Angry & $30(30 \cdot 6)$ & $29(36 \cdot 3)$ & $68(69 \cdot 4)$ & $51(63 \cdot 8)$ & NS \\
\hline Mood - Happy & $1(1 \cdot 0)$ & $3(3 \cdot 8)$ & $97(99 \cdot 0)$ & $77(96 \cdot 3)$ & NS \\
\hline Mood - Tense & $11(1 \cdot 22)$ & $12(15 \cdot 0)$ & $87(88.8)$ & $68(85 \cdot 0)$ & NS \\
\hline
\end{tabular}


medRxiv preprint doi: https://doi.org/10.1101/2021.05.11.21257037; this version posted May 11, 2021. The copyright holder for this preprint (which was not certified by peer review) is the author/funder, who has granted medRxiv a license to display the preprint in perpetuity.

It is made available under a CC-BY-NC-ND 4.0 International license.

Figure 1) Prevalence of neurocognitive, pain and mood symptoms in seronegative and seropositive study participants (Fisher's exact test: $\mathrm{n}=1553,{ }^{*}$ significant at level 0.05)

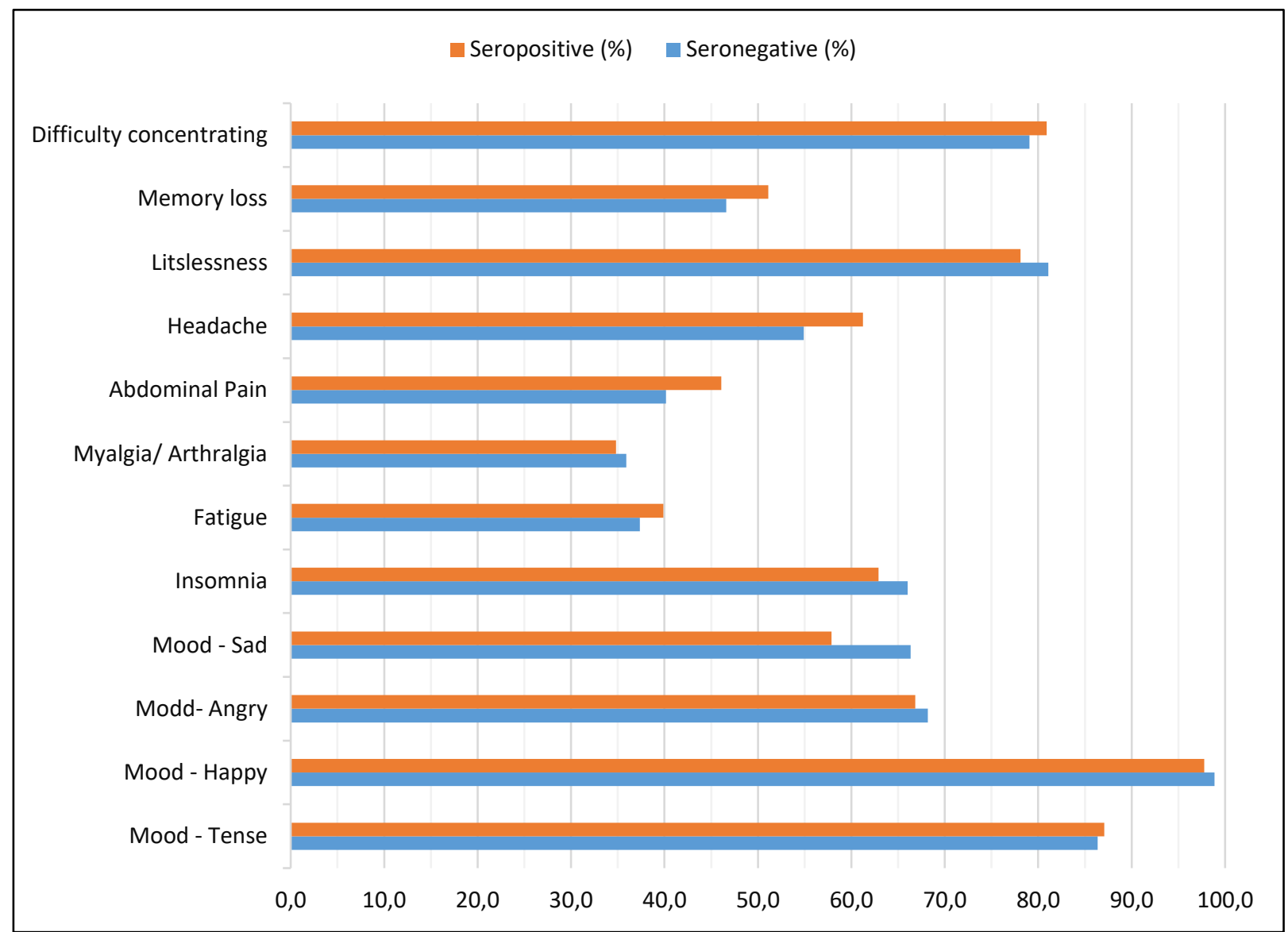


medRxiv preprint doi: https://doi.org/10.1101/2021.05.11.21257037; this version posted May 11, 2021. The copyright holder for this preprint (which was not certified by peer review) is the author/funder, who has granted medRxiv a license to display the preprint in perpetuity.

It is made available under a CC-BY-NC-ND 4.0 International license.

Supplementals - Figure 1) Prevalence of neurocognitive, pain and mood symptoms in LIAISON ${ }^{\circledR}$ negativ and positive study participants (Fisher's exact test: $\mathrm{n}=1553, *$ significant at level $0 \cdot 05$ )

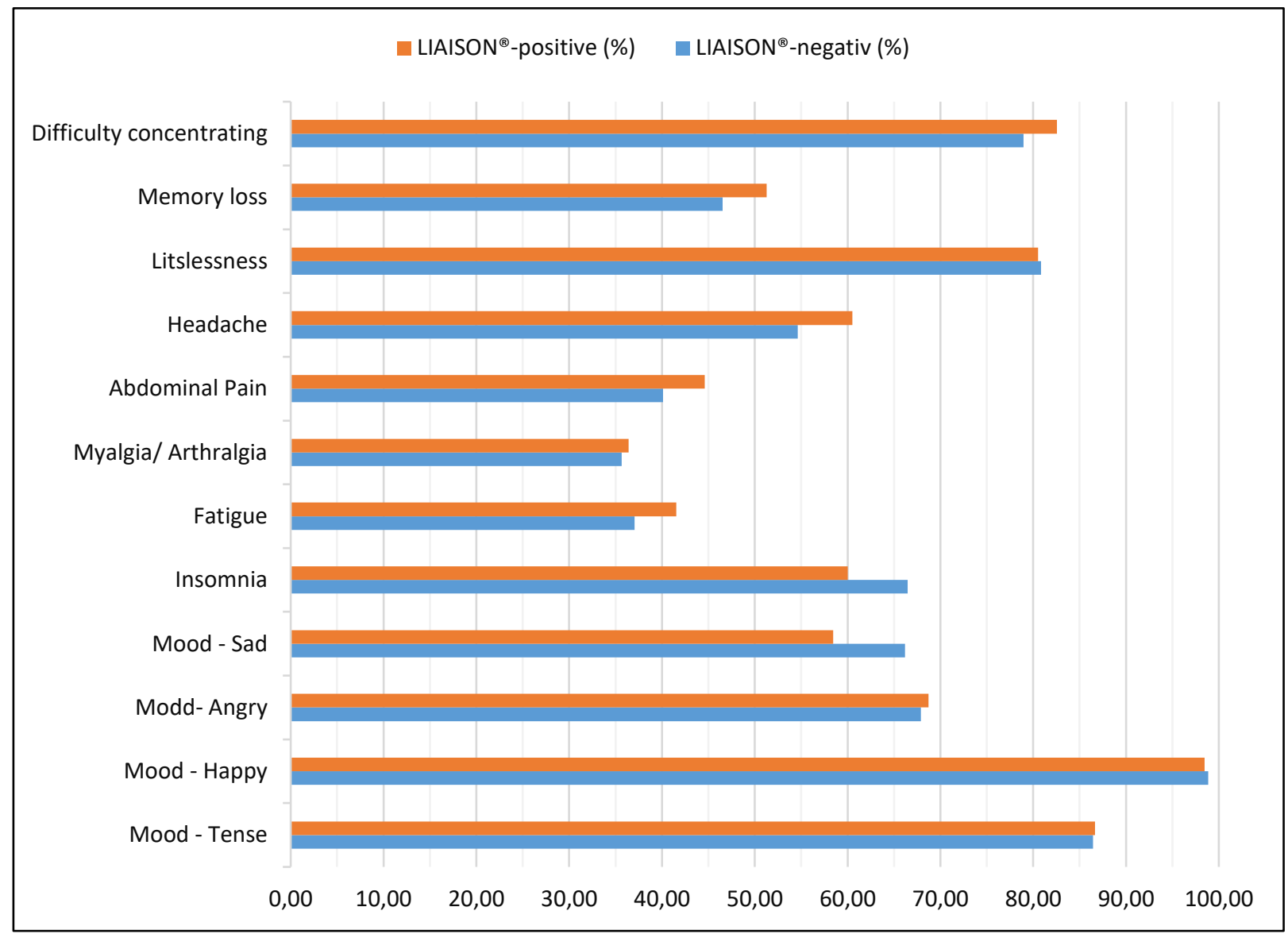

